\title{
Sediment underneath charophyte meadows is enriched in viable ephippia and enhances the benthic periphytic biofilm
}

\author{
María A. Rodrigo (iD) - Eric Puche $(\mathbb{D}) \cdot$ Matilde Segura $(\mathbb{D} \cdot$ Adriana Arnal • \\ Carmen Rojo $\mathbb{D}$
}

Received: 2 June 2021 / Revised: 17 September 2021/ Accepted: 21 September 2021/Published online: 1 October 2021

(C) The Author(s) 2021

\begin{abstract}
We contribute to the knowledge of charophyte meadows as key components of aquatic systems by analysing how they affect wetland sediments. We performed a factorial-design experiment with limnocorrals (outdoor mesocosms) in a Mediterranean protected wetland with presence or absence of charophytes [Chara vulgaris $(\mathrm{CV})$ and Chara hispida $(\mathrm{CH})$, planted from cultures or recruited in situ from germination of their fructifications]. The first $1 \mathrm{~cm}-$ surficial and $2 \mathrm{~cm}$-bottom sediment layers were analysed for cladoceran ephippia, ostracods valves, benthic community of bacteria and periphytic biofilm, and charophyte fructifications. In the surficial sediment, the ephippia density was fourfold higher in the conditions with charophytes than in sites with nocharophytes and higher apparent viability was found. The surficial sediment periphyton biofilm was composed mainly of diatoms, with tenfold higher biomass underneath charophytes, and a much diverse
\end{abstract}

Handling editor: André Padial

Supplementary Information The online version contains supplementary material available at https://doi.org/10.1007/ s10750-021-04702-x.

M. A. Rodrigo $(\bowtie) \cdot$ E. Puche $\cdot$ M. Segura ·

A. Arnal · C. Rojo

Cavanilles Institute of Biodiversity and Evolutionary

Biology, University of Valencia, c/ Catedrático José

Beltrán 2, 46980 Paterna, Spain

e-mail: maria.a.rodrigo@uv.es community. The specific microhabitat generated by each charophyte species was reflected in the different abundances and relationships between the analysed components, firstly establishing a divergence with the sediment without meadows and, secondly, a distinction between the meadows of $\mathrm{CH}$ and $\mathrm{CV}$ that exhibit particular morphology-architecture, might exudate different metabolites and might have different allelopathic capacities over microalgae and microinvertebrates. Thus, the charophyte-sediment tandem is relevant for biodiversity and habitat conservation.

Keywords Outdoor mesocosm experiments . Cladoceran ephippia - Oospores - Ostracod valves . Sediment bacteria $\cdot$ Wetlands

\section{Introduction}

Charophyte (green macroalgae) meadows are a key component of the aquatic system at all water bodies worldwide. They are highly relevant for biogeochemical processes, affect water quality and serve as a refuge, food source, and support for a great variety of aquatic organisms (Blindow et al., 2014). Knowledge exists on the effects of aquatic plants, in general, and of charophytes, in particular, on water quality, but little is known on their effects on sediment quality (Puche et al., 2021). Sediments are important 
compartments because they are the place where the spores and resting stages of many aquatic organisms survive adverse conditions (Alekseev et al., 2007). Therefore, the sediment cannot be overlooked given that it is from where recolonization will start. This is a key issue in the preservation and restoration of aquatic ecosystems, particularly in most Mediterranean wetlands, which have been subjected to a large number of anthropogenic pressures (e.g. desiccation, pollution, etc.) and hence they have lost their charophyte meadows (Blindow, 1992; Rodrigo \& Alonso-Guillén, 2013).

In the sediments, there are invertebrate resting forms whose dispersal and viability are crucial for the development of aquatic communities and to maintain the specific and genetic pool of water bodies (Moreno et al., 2016). This is the case of cladocerans, with critical species in food webs and for ecosystem functioning (Nevalainen \& Luoto, 2017). The fertilized eggs of cladocerans are inside a resistant dormant ephippium which can remain latent in the sediments until the conditions for growth and reproduction are favourable again, preserving, in this way, an adequate number of viable individuals for the population of a certain species which assures the future continuity in the community (Alekseev et al., 2007). Recently, it has been suggested that the tandem formed by charophytes and zooplankton, such as cladocerans, plays a key role in the structure of aquatic networks (Puche et al., 2020). This is due to the protection offered by the vegetation and the provision of food to cladocerans from the epiphytes growing on them and from sediment periphyton, and not exclusively from phytoplankton, hence achieving greater connections in wetland food webs. The ostracods are another group of organisms whose remains (valves), due to their composition of calcium carbonate, are well preserved and can be easily found in sediments. The density of their valves in the surficial sediment layers might be used as indirect evidence of the population size these organisms were able to achieve in previous periods when studying recent sediments (Marco-Barba et al., 2013). Freshwater ostracods, chiefly of benthic habits, feed by filtering mainly microalgae from the periphyton, animal debris and detritus (Meisch, 2000). The microbial benthic community (i.e. periphyton, bacteria) is also related to sediments. The periphyton biofilm and the bacteria underneath play significant roles in the primary productivity, energy flow, and nutrient cycling in aquatic ecosystems (Canfield et al., 2010; Morina et al., 2018). The periphyton biofilm, developed on the surficial sediments which receive photosynthetically active radiation, is formed by a variety of autotrophic and heterotrophic microbes, mostly benthic microalgae and cyanobacteria, but also bacteria and benthic, attached or not, grazers (van Dam et al., 2002). As stated above, it plays an important role in the connexion among the benthos, the habitat created by the charophyte meadows, and the pelagic compartment (van Dam et al., 2002; Puche et al., 2020). In addition to this complex structure in the upper sediment layers, the microbial community also shows a relevant biogeochemical activity in the sub-surficial sediments. All this can be influenced by the presence of charophytes (Puche et al., 2021). Furthermore, charophytes produce fructifications (oospores, the fertilized oogonium, and gyrogonites, when the oospore is covered by an outer calcified layer) which stay in the sediments. They remain viable over long periods (from years to decades; Rodrigo et al., 2010). These propagules are the crucial reserves for the establishment of future vegetation (Rodrigo \& Alonso-Guillén, 2013), particularly in temporary aquatic environments.

The Albufera de Valencia Natural Park is a nationally and internationally recognized wetland because of its cultural and natural singularity, which includes the largest coastal lagoon in the Iberian Peninsula; however, it is affected by a strong cultural eutrophication process. Within this park, the reserve area called the Tancat de la Pipa was created in 2009. Several studies have been undertaken in the area dealing with the role of charophytes in newly created ponds for restoration purposes (Rodrigo et al., 2015), or the effect of macrophytes on eutrophication reversion and biodiversity enhancement (Rodrigo et al., 2018), as well as the selection of macrophytes species for replanting in Mediterranean wetlands (Rodrigo \& Carabal, 2020). However, the relationship of charophyte meadows and the sediment remains less explored in this particular habitat and there are very few studies concerning this in other systems. Thus, our main goal is to delve into the relationships established in the charophyte-sediment tandem for the functioning and conservation of shallow aquatic ecosystems. In 2018, we performed a field experiment with outdoor mesocosms (limnocorrals) set up in the Tancat de la Pipa to unravel how charophyte meadows mediate the 
response of the sediment microbial community to global change-related factors (e.g. UV radiation, Puche et al., 2021). The species Chara hispida L. (CH) was used to develop the meadows. It was demonstrated how the sediment microbial community of a wetland is harmed by UV radiation, and how this charophyte mitigates such effects. Now, we go several steps further and want to analyse the influence of the charophyte meadows (but considering a different species, Chara vulgaris L., to assess whether or not there are species-specific differences) on the presence of zooplanktonic and zoobenthic organisms, such as cladocerans and ostracods, analysing the ephippia and valves, respectively, buried in the sediment as well as on the sediment microbial community (periphytic biofilm and bacteria), and on the enrichment of the oospore bank. Moreover, we examine the effect of a dry period on the recruitment of $\mathrm{CH}$ from the previous experiment and its influence on the above-mentioned variables. Submerged macrophytes favour the abundance and diversity of zooplankton in the water column in comparison to vegetation-free zones (e.g. Meerhoff et al., 2007). Among the reasons proposed are the habitat provided by the vegetation, the refuge effect offered by the meadows against zooplankton predators, and the high degree of environmental heterogeneity provided by the vegetation. Therefore, our hypotheses are: (i) the presence of charophyte meadows will benefit the abundance of cladocerans and ostracods in the water and this will be reflected in their sediment remains, but (ii) there will be speciesspecific differences depending on particular traits of each charophyte species, (iii) the presence of charophytes will be a potential substrate for better conservation of cladoceran resting eggs, (iv) the presence of charophytes will increase the periphytic biofilm (and bacterial) biomass and different charophyte species will have a different composition associated, and (v) the dry period will change the composition of periphyton biofilm in favour of more adapted species, and will stimulate the germination of charophyte oospores.

\section{Materials and methods}

Study area and experimental setup

The experiment was performed in the protected wetland called Tancat de la Pipa $\left(39^{\circ} 21^{\prime} 51^{\prime \prime} \mathrm{N}-0^{\circ}\right.$ $20^{\prime} 47^{\prime \prime} \mathrm{W}$; Albufera de València Natural Park, Spain), which nowadays is a reserve area. This natural park has been included among the "international important wetlands" by the Ramsar Agreement, and designated as a special area for bird protection. It is also part of the Natura 2000 database. However, the natural park area is highly anthropized due to agricultural use, fishing and tourism, among others. Tancat de la Pipa wetland is a 40-ha area formerly occupied by rice fields which was transformed into a pilot zone to test methods of improving water quality, enhancing species and habitat conservation and performing restoration practices (Rodrigo et al., 2013, 2015; Rodrigo \& Carabal, 2020) (Fig. 1A).

Within the Tancat de la Pipa wetland, the experiment was performed in a small shallow lagoon called the Educative lagoon (5 ha, $60 \mathrm{~cm}$ maximum depth; Fig. 1A), which was dried out in August 2018 for management purposes (retrieval of exotic fish and enhancing macrophyte recruitment) until February 2019 when it was re-flooded with the usual water that feeds the area (running water from two channels; Fig. 1A). After this flooding, we set up 12 limnocorrals on 26th February 2019, placed in three rows of 4 limnocorrals each, at a distance of approximately $1 \mathrm{~m}$ from each other in between the former 12 limnocorrals deployed on 13th April 2018 where $\mathrm{CH}$ was planted in half of them (Puche et al., 2021). The treatment in the new limnocorrals consisted of planting $C$. vulgaris in half of them, which were established randomly (Fig. 1B). The limnocorrals consisted of four rigid plastic rods, each one being $85 \mathrm{~cm}$ in length, located as the sides of a quadrilateral measuring $50 \mathrm{~cm}$ on each side $\left(2500 \mathrm{~cm}^{2}\right)$, which were buried in the substrate at a depth of $20 \mathrm{~cm}$. A $50-\mathrm{cm}$ wide plastic mesh with $1 \mathrm{~cm}$ pore openings was wrapped around these four rods, preventing the entry of fish and crayfish (Rodrigo et al., 2013); the tops of the quadrilaterals were covered with $4 \mathrm{~cm}$ pore net sheets, designed to prevent birds grazing on the macrophytes (Fig. 1C, D).

For the $C$. vulgaris treatment, 16 small pots $(4.6 \mathrm{~cm}$ diameter) with charophytes belonging to laboratory stocks (originally collected from nearby locations) 

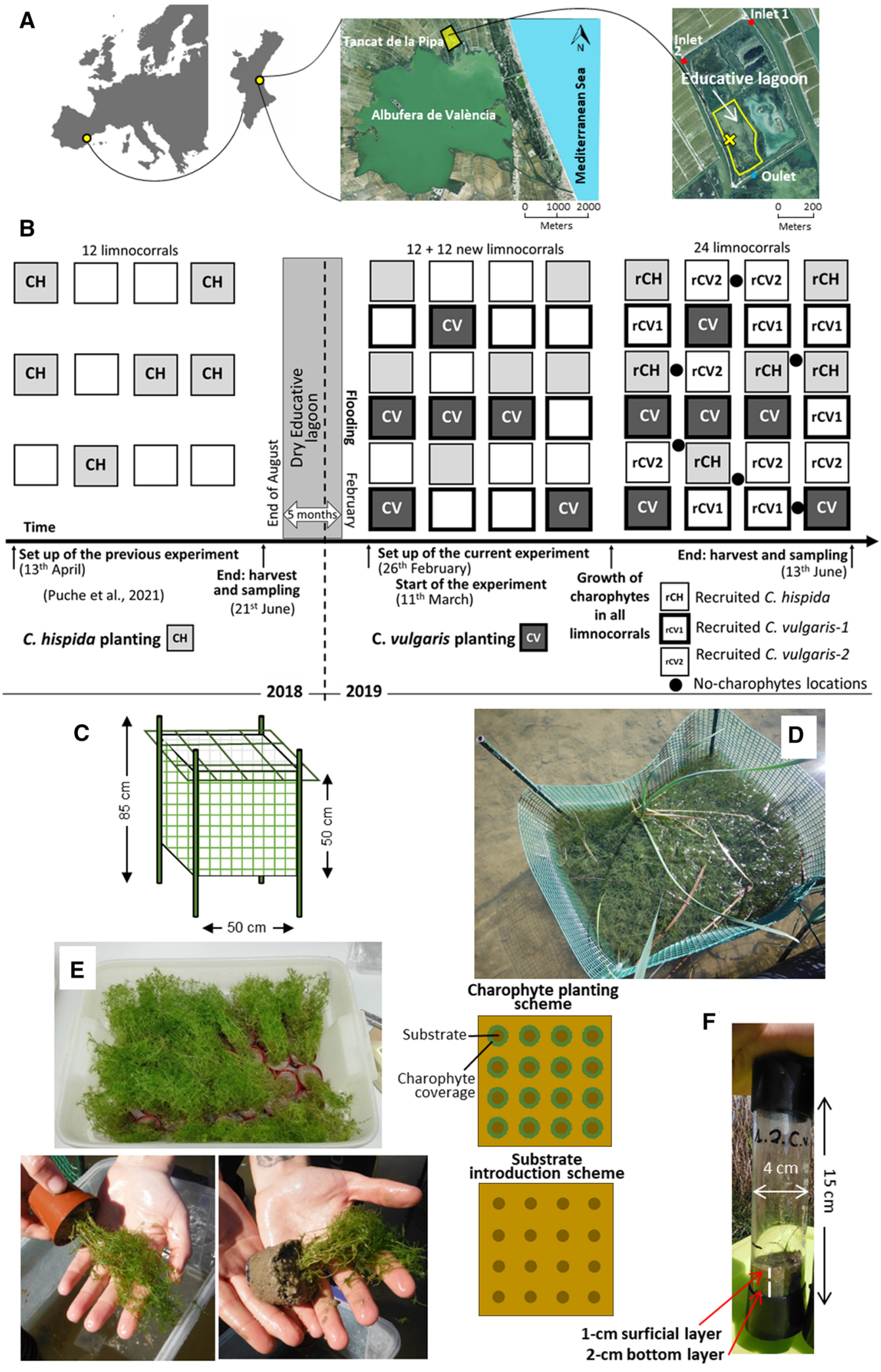
4Fig. 1 A Location of the Educative lagoon in the Tancat de la Pipa and within the Albufera de València Natural Park. The location of the limnocorrals is highlighted with a cross. B Design of the limnocorral setup with the different treatments, plus the six outside locations with no charophytes. C and D: Sketch of the limnocorrals specifying their dimensions and a photograph of one of them under the CV condition (notice the absence of charophytes outside the limnocorral). E Cultures of Chara vulgaris produced in the laboratory. A culture, with and without the pot, ready to be planted in the limnocorrals. The arrangement of the 16 cultures planted in each limnocorral with charophytes and the substrate in the treatment with no charophytes. F Photograph of a sediment core specifying its dimensions and the visually differentiable surficial and bottom layers

were planted into each limnocorral (Fig. 1E). These pots were transplanted, keeping the small portion of substrate (a mixture of previously autoclaved sediment and commercial sand, 1:1; Puche et al., 2021) which held the rhizoids to ensure their stability in the new site. Thus, approximately $10 \%$ of the sediment surface of the limnocorrals was substituted by introduced substrate, and the charophyte surface coverage after planting was $30 \%$. To maintain the same conditions, the substrates of 16 stock pots without charophytes (treated in the same way as the charophyte pots) were added to the sediment in the "nocharophyte" limnocorrals to simulate the same disturbance on the sediment (Fig. 1E). Once the installation was completed, and after a few weeks of acclimatization, we set the initial time of the experiment (11th March 2019), which lasted until 13th June 2019. The different limnocorrals were visited monthly by kayak to avoid disturbing the sediment of the area and producing resuspension. Each limnocorral was opened up just enough to collect data, take samples, or take photographs.

The desiccation period effectively stimulated the recruitment of charophytes from the sediment propagules after re-flooding, and at the end of the experiment there was a quite dense coverage of charophytes in all 24 limnocorrals. Therefore, we could study five different conditions: (1) 2019-planted C. vulgaris (CV hereafter), (2) recruited $\mathrm{CV}$ in the limnocorrals where no $\mathrm{CV}$ was planted $(\mathrm{rCV}-1$ hereafter), (3) recruited $\mathrm{CH}$ in the limnocorrals which were planted with $\mathrm{CH}$ in 2018 (rCH hereafter), (4) recruited CV in the limnocorrals where no $\mathrm{CH}$ was planted in 2018 (rCV-2 hereafter), and (5) locations outside the limnocorrals with no charophytes which were randomly established among the limnocorrals. There were then six replicates of each condition, which meant a total of 24 limnocorrals plus six sites sampled with no vegetation (Fig. 1B). During the time of the experiment, the charophytes grew until they reached a maximum coverage of $100 \%$ (Fig. 1D), which represented a maximum biomass (no carbonates eliminated) of $3390 \mathrm{~g}$ dry weight (DW)/m² for CV, $3021 \mathrm{~g}$ $\mathrm{DW} / \mathrm{m}^{2}$ for $\mathrm{rCV}-1$ and $\mathrm{rCV}-2$ and $1918 \mathrm{~g} \mathrm{DW} / \mathrm{m}^{2}$ for $\mathrm{rCH}$. The recruited $\mathrm{CV}$ [C. vulgaris var. longibracteata (Kütz.) Groves \& Bull.] in $\mathrm{rCV}-1$ and rCV-2 was a different variety to the planted one.

At the end of the experiment, three sediment cores (4 cm diameter, $15 \mathrm{~cm}$ height; Fig. $1 \mathrm{~F}$ ) were extracted from each limnocorral in order to include the possible spatial heterogeneity due to the treatment. Moreover, a core was obtained from each location with no charophytes. Once the cores were extracted, they were kept in a vertical position to avoid the mixing of the sediment, since it was intended to preserve the different layers with complete integrity for further analyses. In each core, two layers of the substrate were distinguishable according to their coloration and the presence of primary producers: a lighter surface part (1 cm thick) corresponding to the oxygenation zone where the periphytic biofilm was located (surficial layer hereafter), and a deeper layer (2 cm thick), darker in colour, corresponding to the mainly anoxic part (bottom layer hereafter) (Fig. 1F). In the field, these layers were separated and kept in sterile plastic pots. Once in the laboratory, the surficial parts of the three cores of each limnocorral were homogenized; this process was repeated with the three bottom layers.

Density determination of charophyte fructifications, cladoceran ephippia and ostracod valves

The 60 sediment samples for these determinations were allowed to dry since processing all of them takes a long time. The DW of each sample was determined with a precision scale, rehydrated with tap water and sequentially sieved using 1000, 500 and $200 \mu \mathrm{m}$ mesh sizes. After sieving, each fraction was analysed using a stereomicroscope and a Bogorov counting tray. Charophyte fructifications and cladoceran ephippia were picked out by means of a brush, and/or forceps, and separated by species in the case of charophyte remains, and into two categories (1 egg and 2 eggs 
ephippia) for cladoceran resting eggs. The charophyte remains consisted of (i) oospores formed by the organic cell wall produced around the fertilized eggcell, and (ii) gyrogonites, which are the calcified oospores. Fructifications were distinguished as "apparently" viable and non-viable. Apparently viable fructifications were defined as intact and hard oospores, which did not deform when they were pressed with the forceps and had "healthy" starch granules inside (Rodrigo et al., 2010). Oospores not meeting these criteria plus broken fructifications were considered non-viable. Charophyte fructifications were assigned to species based on morphological measurements (length as largest polar axis and width as largest equatorial axis of the wet specimens) and by comparing them with the information found in Rodrigo et al. (2010). These authors analysed the charophyte fructifications in the sediments of the study site. Nitella and Tolypella spp. were easily distinguishable. $\mathrm{CH}$ fructifications are much larger than those of CV. Fructifications belonging to the genus Chara which did not fit in the measurement range of $\mathrm{CH}$ and $\mathrm{CV}$ were designated as Chara spp. Ephippia were considered apparently viable when they were intact and had a "healthy" appearance. Broken and "soft" ephippia (deformed when pressed down with the forceps) were considered as non-viable. Ostracod valves were also counted, as individual valves (dividing by 2 for calculations of density) and as two-valve remains. The presence of other types of organism remains (such as foraminifers) was recorded. The densities of the remains were expressed per gram of DW sediment.

\section{Bacterial density determination}

Sample preparation for counting by flow cytometry was carried out from an adaptation of the dilution/fixation/staining protocol to analyse freshwater bacteria in lake sediments according to Puche et al. (2021). First, $0.5 \mathrm{ml}$ of sediment was taken and transferred to a test tube where $3 \mathrm{ml}$ of phosphate-buffered saline solution was added (as the sediment was quite aqueous, it was pipetted easily from the collected sample). Then, for its fixation, $350 \mu \mathrm{l}$ of a mixture of $10 \%$ formaldehyde + glutaraldehyde (PAGA) was added. Subsequently, for the separation of the biological particles from inert ones in the sediment, $1 \mathrm{ml}$ of $0.01 \mathrm{M}$ sodium pyrophosphate, $5 \mu \mathrm{l}$ of $10 \%$ sodium dodecyl sulphate (SDS) and $4 \mathrm{ml}$ of Milli-Q water were added to the sample. Next, the sample was placed in an Elmasonic $\mathrm{S} 30 \mathrm{H}$ ultrasound bath for $3 \mathrm{~min}$, interrupting this treatment every minute for $30 \mathrm{~s}$ of manual shaking. Finally, the sample was incubated on ice for $15 \mathrm{~min}$, followed by one minute of manual shaking. After this, the sample was centrifuged in a Sorvall ST $16 \mathrm{R}$ centrifuge at $800 \times g$ for a minute. To eliminate any large particles in the sediment (ones greater than $5 \mu \mathrm{m}$ give erroneous signals in the cytometer), the supernatant obtained after centrifugation was filtered through a $5 \mu \mathrm{m}$ pore size membrane and finally, the sample was diluted at a 1:400 ratio with Milli-Q water. After processing and dilution of the sediment sample, an aliquot of $0.5 \mathrm{ml}$ was extracted and stained with $20 \mu \mathrm{l}$ of SYBR Green II and incubated in the dark for $30 \mathrm{~min}$. SYBR Green II is a fluorescent marker that adheres to DNA, exciting at $497 \mathrm{~nm}$ (with a secondary excitation peak at $254 \mathrm{~nm}$ ) and emitting fluorescence at $520 \mathrm{~nm}$ (corresponding to the green channel of the cytometer, FL1). Once each sample was prepared, it was put into the cytometer (Cytomics FC 500 Beckman Coulter) and a high flow rate for $120 \mathrm{~s}$ was programmed; this process was repeated three times per sample in three different sessions. These results were analysed with the specific program Flowing Software 2. A dot plot was made with channels FL1 and FL4, which discriminate bacteria from other particles since bacteria stained with SYBR Green II have a maximum emission collected by channel FL1, and a minimum collected by FL4. From this graph, the region corresponding to the bacteria was delimited. In parallel, the water content of the sediment was assessed by weighing aliquots of this sediment [fresh weight (FW) initially and DW after $24 \mathrm{~h}$ at $70{ }^{\circ} \mathrm{C}$ ]; the relationship between $\mathrm{FW}$ and DW of the sediment was calculated by measuring them from aliquots of all samples $(\mathrm{DW}=0.179 \times$ $\left.\mathrm{FW} ; R^{2}=0.99\right)$. Thus, bacterial counting was normalized by the grams of DW sediment considered for the sample, and, in this way, the number of bacteria per gram of DW sediment for each layer and each limnocorral was obtained.

Abundance and composition of microalgae and cyanobacteria in periphyton

To study the periphyton biofilm, a fraction of the sediment from the surficial layer of each core was 
Fig. 2 PCA-biplot of the different assemblages of all surficial sediment components considered in the different limnocorral conditions and the dependent variables directions. $C V$ : 2019-limnocorrals with planted Chara vulgaris, rCH: 2018-limnocorrals with recruited Chara hispida, $r C V$-1:

2019-limnocorrals with recruited Chara vulgaris var. longibracteata, $r \mathrm{CV}-2$ : 2018-limnocorrals with recruited Chara vulgaris var. longibracteata, Nocharoph: sites without charophytes

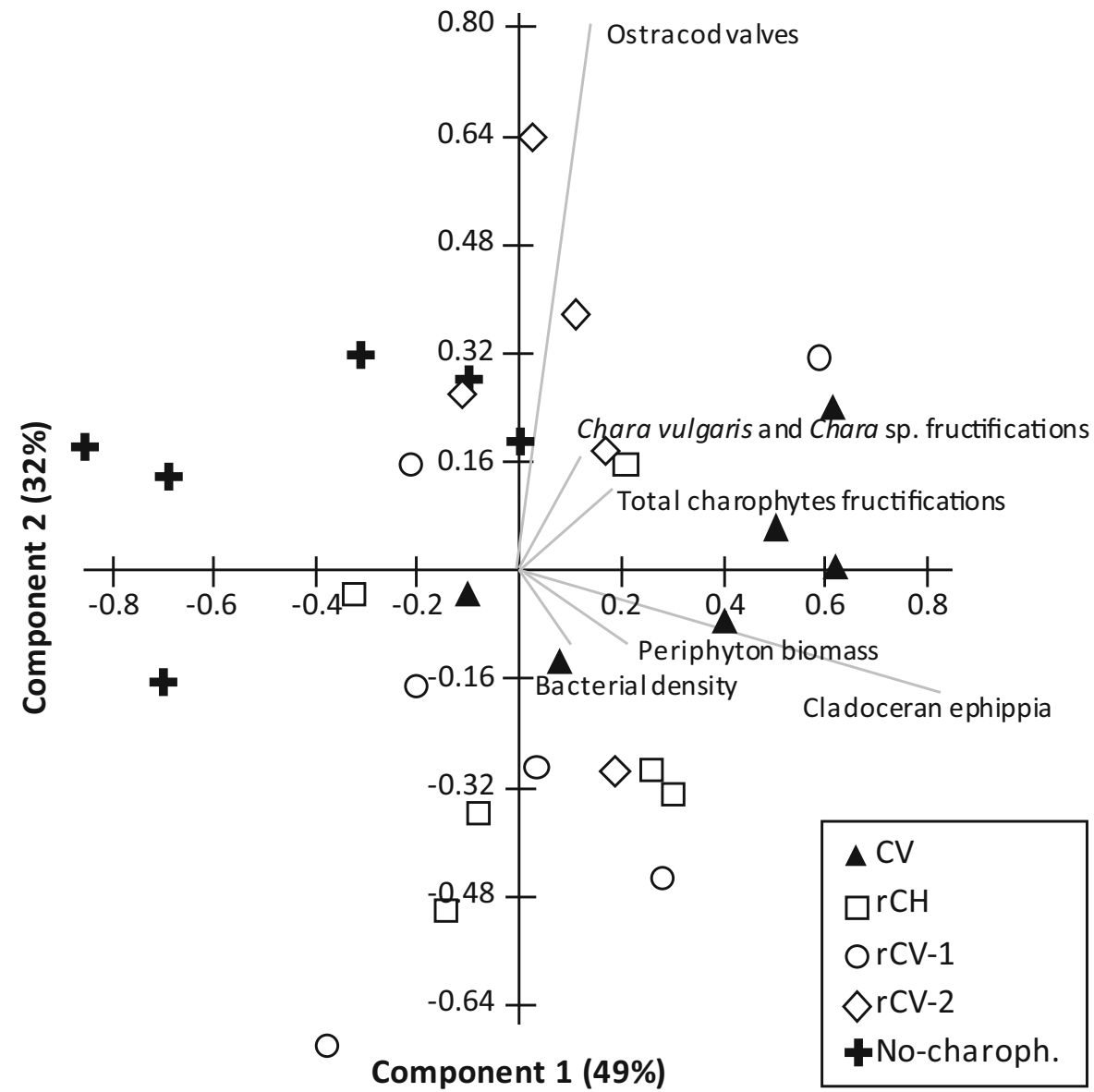

weighed (FW) and the correspondence with DW was determined as described above. This fraction was washed by stirring in $50 \mathrm{ml}$ of deionized water; this water, preserved with a Lugol's iodine solution, was the sample used to observe the organisms. Taxonomic classification (at the finest possible resolution), counts, and measurements of the organisms were conducted using Utermöhl chambers under an inverted microscope at $\times 400$ and $\times 1000$ magnification following standard protocols. To determine whether most of the periphytic species richness of each assemblage was covered, a species accumulation curve was plotted as a saturating criterion. Counted individuals were single cells, colonies, and filaments; their biovolume was calculated (for more details see Rojo et al., 2017a). The biomass of each taxon and site was expressed as $\mathrm{mm}^{3} / \mathrm{g}$ DW sed. Diversity of the periphytic community was expressed as richness, Shannon index (calculated on $\ln _{\text {biovolume }}$ ) and the effective number of species $\left(e^{\mathrm{H}}\right)$. Phytoplankton size was standardized by converting biovolume to equivalent spherical diameter (ESD). We assume edible organisms to be those with an ESD $<20 \mu \mathrm{m}$.

Statistical methods

The normality of the residuals and the homoscedasticity of the variances, the criteria necessary to be able to apply an analysis of variance (ANOVA), were verified by means of Shapiro-Wilk and Levene tests, respectively. When both circumstances were met, oneway ANOVAs were performed to study the effect of the conditions on the mean of the different studied variables and post hoc Tukey tests were applied. When the requirements for the ANOVA were not met, nonparametric tests were used (i.e. Kruskal-Wallis and Mann-Whitney tests). The Bray-Curtis index of similarity was used to cluster the samples based on their periphytic composition (\% species biovolume). SIMPER analyses, which decompose the Bray-Curtis 


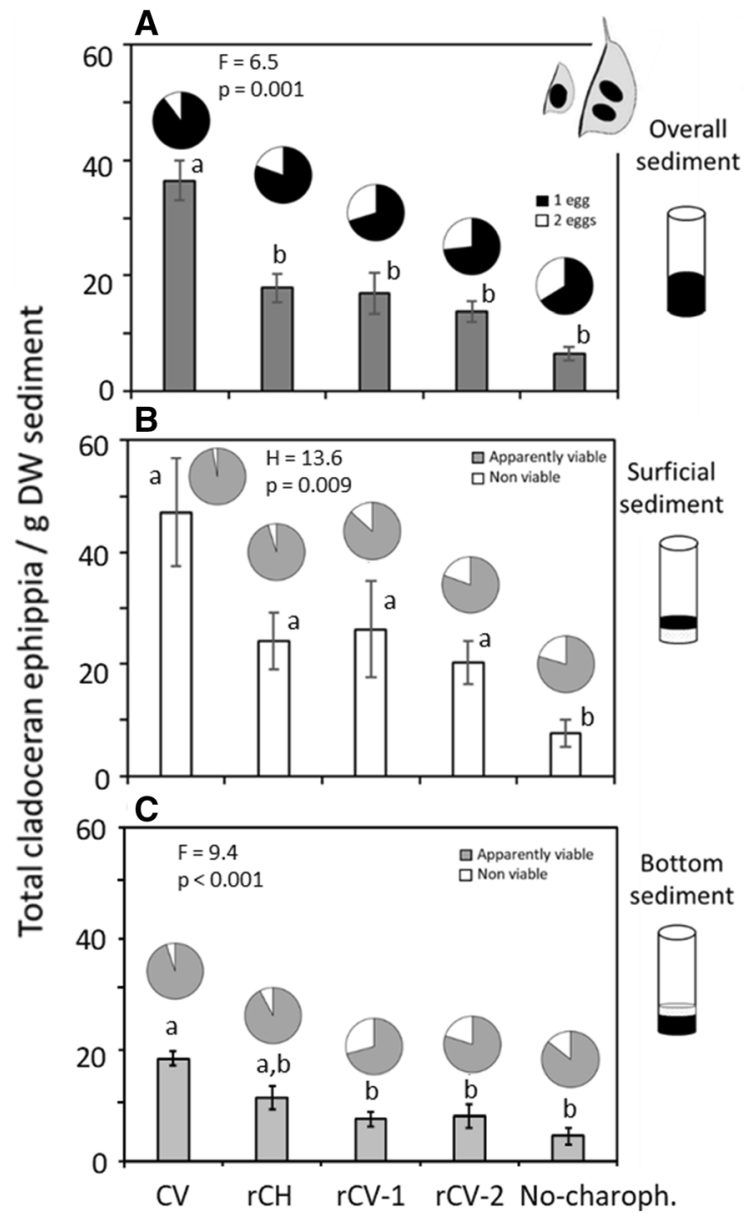

Fig. 3 Density of total ephippia in the $3 \mathrm{~cm}$ sediment layers (A), in the $1 \mathrm{~cm}$ surficial (B) and in the $2 \mathrm{~cm}$ bottom (C) sediment layers under the different conditions. Abbreviations as in Fig. 2. Vertical thin bars indicate standard errors $(n=6)$. ANOVA $F$ or Kruskal-Wallis $H$ and $P$-values are shown on each graph. Lower-case letters represent significant differences between treatments after post hoc tests. The sector graphs in A represent the mean percentage of 1 egg and 2 egg cladoceran ephippia in each condition. The sector graphs in $\mathbf{B}$ and $\mathbf{C}$ represent the mean percentage of apparent viability in the cladoceran ephippia

dissimilarity index, were used to detect the microalgae which contribute most to differences among periphyton assemblages in the different conditions. Pearson correlations were made among organism groups found in the sediment which might reflect the history of their interactions. Since the densities of the studied organisms were not homogeneous in the different conditions, we performed a MANOVA analysis, which, based on these organisms in the surficial sediment, would indicate whether we are facing different

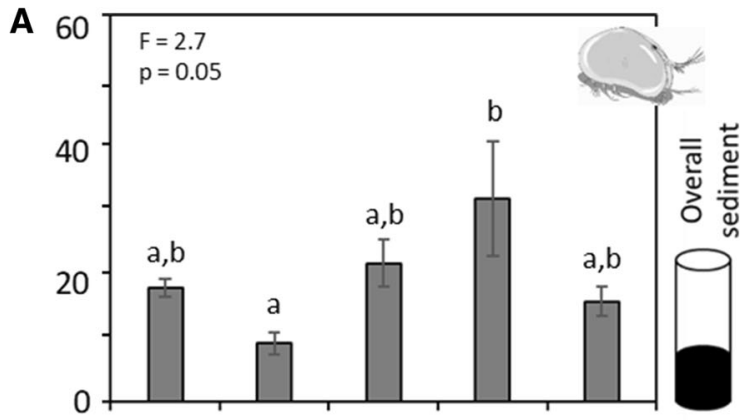

B
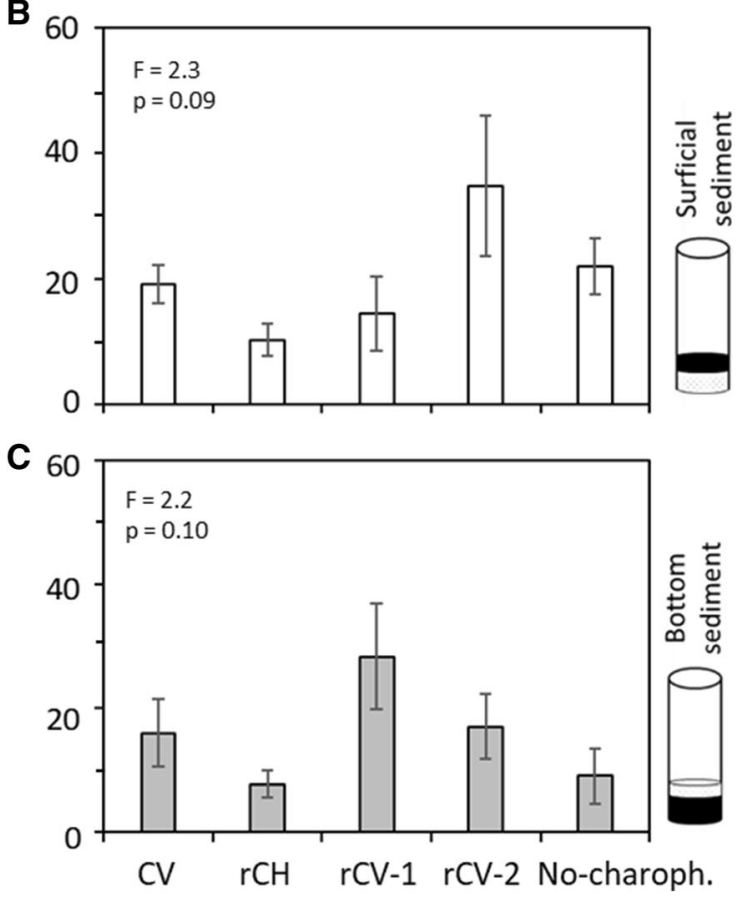

Fig. 4 Density of ostracod doubled-valves in the $3 \mathrm{~cm}$ sediment layers (A), in the $1 \mathrm{~cm}$ surficial (B) and in the $2 \mathrm{~cm}$ bottom (C) sediment layers under the different conditions. Abbreviations as in Fig. 2. Vertical thin bars indicate standard errors $(n=6)$. ANOVA $F$ and $P$-values are shown on each graph. Lower-case letters represent significant differences between treatments after post hoc tests

assemblages depending on the presence or not of charophytes, and depending on the particular charophyte species forming the meadow. A principal component analyses was also performed. Significant differences were considered at $P<0.05$. Statistical analyses were carried out using PAST 3.14 and SPSS Statistics v.22 software. 


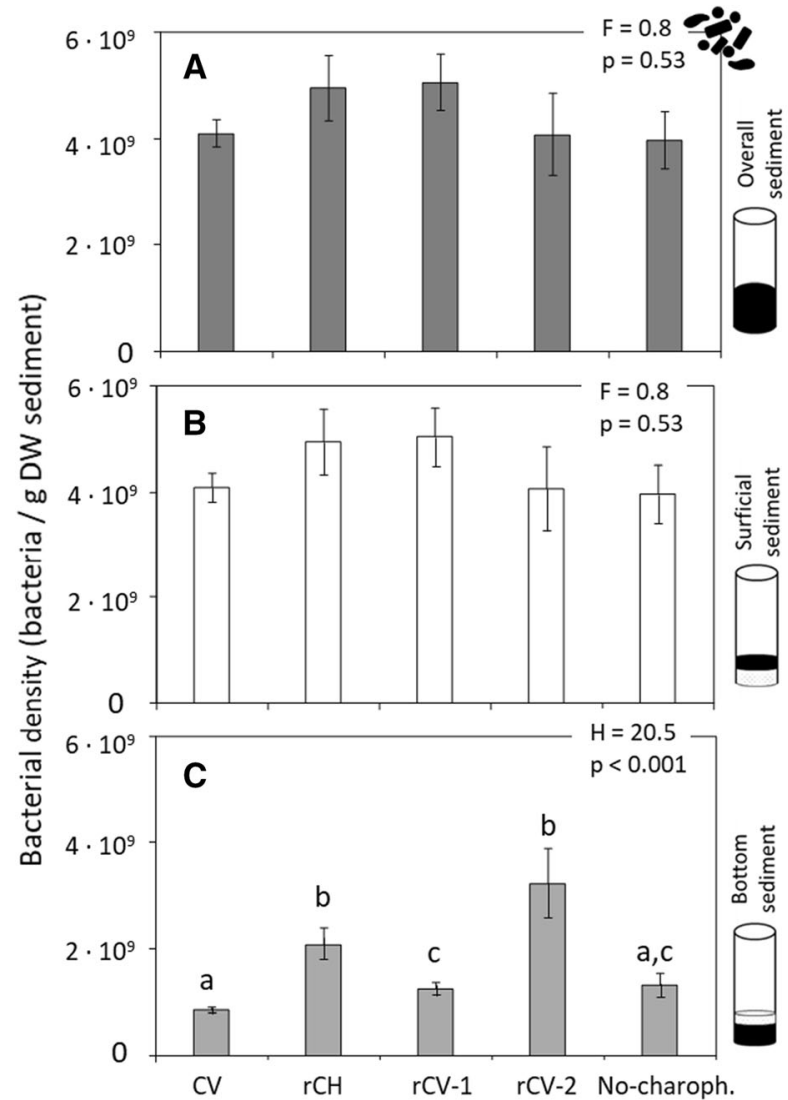

Fig. 5 Bacterial density in the 3-cm sediment layers (A), in the $1 \mathrm{~cm}$ surficial (B) and in the $2 \mathrm{~cm}$ bottom (C) sediment layers under the different conditions. $\mathbf{D}$ and $\mathbf{E}$ Periphyton richness and biomass in the 1-cm surficial sediment layer. The sector graphs in $\mathbf{E}$ represent the biomass share of each taxon. Vertical thin bars

\section{Results}

The assemblages of organism's remains found in the surficial sediment in the different conditions turned out to be statistically different (Pillai trace 1.5; $P<0.001$ ), and the assemblages found in the sediment with charophytes were different from those in the no-charophytes ones; moreover, there was biota discrimination based on the $\mathrm{CV}$ versus $\mathrm{rCH}$ conditions (Table A2). In the PCA biplot representation (Fig. 2), all the vectors of the dependent variables were in the coordinates where mainly the samples from charophyte-sediments were located (positive part of component 1), and these samples were segregated in component 2 , mainly by the presence of ostracods linked to $\mathrm{rCV}-2$ and cladoceran remains close to $\mathrm{CV}$.

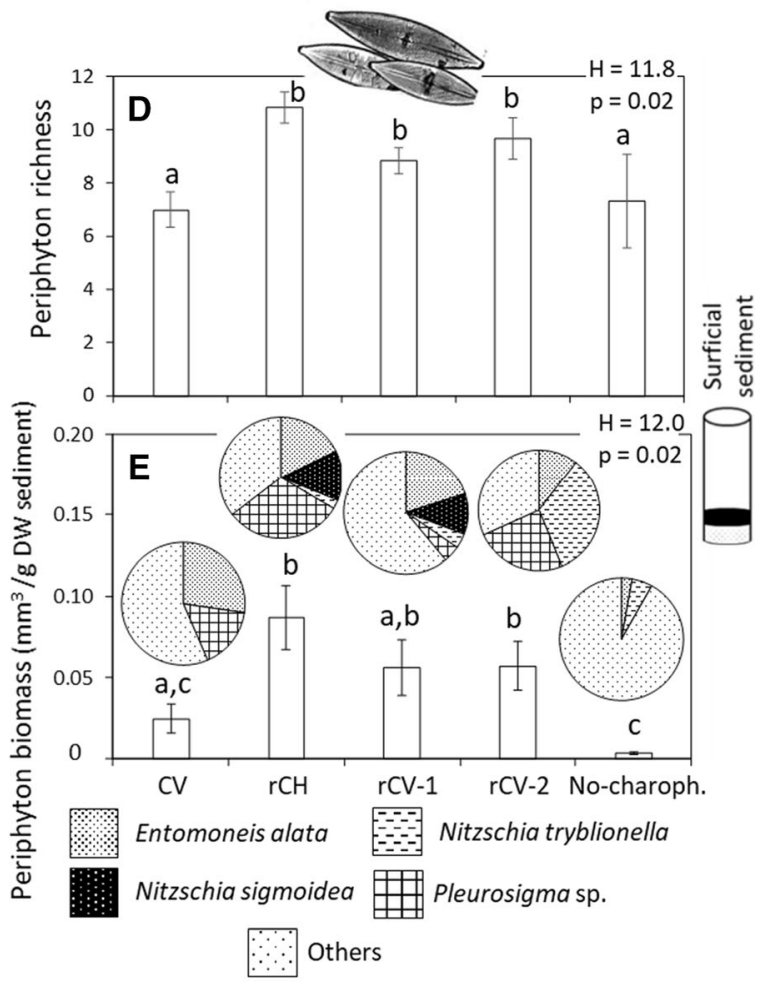

indicate standard errors $(n=6)$. ANOVA $F$ or Kruskal-Wallis $H$ and $P$-values are shown. Lower-case letters represent significant differences between conditions after post hoc tests. Abbreviations as in Fig. 2

Fructifications, periphyton, and bacteria discriminated less among the conditions with charophytes.

In the overall sediment $(3 \mathrm{~cm})$, most of the cladoceran resting eggs contained $1 \mathrm{egg}$, ranging from 66 to $90 \%$ depending on the condition (Fig. 3A). The mean density of total cladoceran resting eggs was statistically the highest in the CV limnocorrals, with $37 \pm 8$-standard error-ephippia/g DW sed. The other three conditions with recruited meadows showed a mean of $16 \pm 2$ ephippia/g DW sed. In the sites with no charophytes the mean density was only $6 \pm 2$ ephippia/g DW sed. (although not significantly different from the recruited group). In the surficial layer (Fig. 3B), the mean density of ephippia in the conditions with charophytes was not statistically different and it was higher than in the condition with no charophytes $(30 \pm 4$ vs. $7 \pm 2$ ephippia/g DW 
Table 1 Pearson correlation values $(r)$ among the different organism groups in the surficial sediment

\begin{tabular}{|c|c|c|c|c|c|}
\hline & $\begin{array}{l}\text { Cladoceran } \\
\text { ephippia }\end{array}$ & $\begin{array}{l}\text { Ostracode } \\
\text { valves }\end{array}$ & $\begin{array}{l}\text { Total charophytes } \\
\text { fructifications }\end{array}$ & $\begin{array}{l}\text { Chara vulgaris and Chara } \\
\text { spp. fructifications }\end{array}$ & $\begin{array}{l}\text { Periphyton } \\
\text { biomass }\end{array}$ \\
\hline \multicolumn{6}{|l|}{ All limnocorrals } \\
\hline Ostracode valves & -0.02 & & & & \\
\hline $\begin{array}{l}\text { Total charophytes } \\
\text { fructifications }\end{array}$ & 0.16 & 0.25 & & & \\
\hline $\begin{array}{l}\text { Chara vulgaris and Chara } \\
\text { spp. fructifications }\end{array}$ & 0.11 & 0.19 & $0.78 * * *$ & & \\
\hline Periphyton biomass & -0.02 & 0.08 & $0.44 * *$ & 0.00 & \\
\hline Bacterial density & -0.05 & -0.23 & 0.00 & 0.00 & 0.12 \\
\hline \multicolumn{6}{|l|}{$\mathrm{rCH}$} \\
\hline Ostracode valves & -0.08 & & & & \\
\hline $\begin{array}{l}\text { Total charophytes } \\
\text { fructifications }\end{array}$ & 0.28 & $0.82 * *$ & & & \\
\hline $\begin{array}{l}\text { Chara vulgaris and Chara } \\
\text { spp. fructifications }\end{array}$ & -0.26 & 0.40 & 0.51 & & \\
\hline Periphyton biomass & 0.35 & $0.79 *$ & $0.94 * * *$ & 0.30 & \\
\hline Bacterial density & -0.56 & 0.36 & -0.22 & -0.10 & -0.24 \\
\hline \multicolumn{6}{|l|}{$\mathrm{CV}$} \\
\hline Ostracode valves & $0.76^{*}$ & & & & \\
\hline $\begin{array}{l}\text { Total charophytes } \\
\text { fructifications }\end{array}$ & 0.28 & 0.26 & & & \\
\hline $\begin{array}{l}\text { Chara vulgaris and Chara } \\
\text { spp. fructifications }\end{array}$ & -0.01 & 0.04 & $0.91 * * *$ & & \\
\hline Periphyton biomass & 0.19 & 0.69 & 0.41 & 0.46 & \\
\hline Bacterial density & -0.20 & -0.6 & 0.12 & 0.15 & -0.7 \\
\hline \multicolumn{6}{|l|}{ rCV1-rCV2 } \\
\hline Ostracode valves & 0.06 & & & & \\
\hline $\begin{array}{l}\text { Total charophytes } \\
\text { fructifications }\end{array}$ & -0.09 & 0.49 & & & \\
\hline $\begin{array}{l}\text { Chara vulgaris and Chara } \\
\text { spp. fructifications }\end{array}$ & -0.03 & 0.36 & $0.84 * * *$ & & \\
\hline Periphyton biomass & $-0.71 * * *$ & 0.19 & 0.19 & 0.15 & \\
\hline Bacterial density & 0.13 & 0.13 & -0.18 & -0.04 & 0.11 \\
\hline \multicolumn{6}{|l|}{ No-charophytes } \\
\hline Ostracode valves & 0.31 & & & & \\
\hline $\begin{array}{l}\text { Total charophytes } \\
\text { fructifications }\end{array}$ & 0.65 & -0.38 & & & \\
\hline $\begin{array}{l}\text { Chara vulgaris and Chara } \\
\text { spp. fructifications }\end{array}$ & 0.73 & -0.29 & $0.99 * * *$ & & \\
\hline Periphyton biomass & 0.12 & 0.45 & -0.52 & -0.48 & \\
\hline Bacterial density & -0.1 & -0.47 & 0.53 & 0.49 & $-1.00 * * *$ \\
\hline
\end{tabular}

Abbreviations as in Fig. 3

$* P<0.05, * * P<0.01, * * * P<0.001$ 

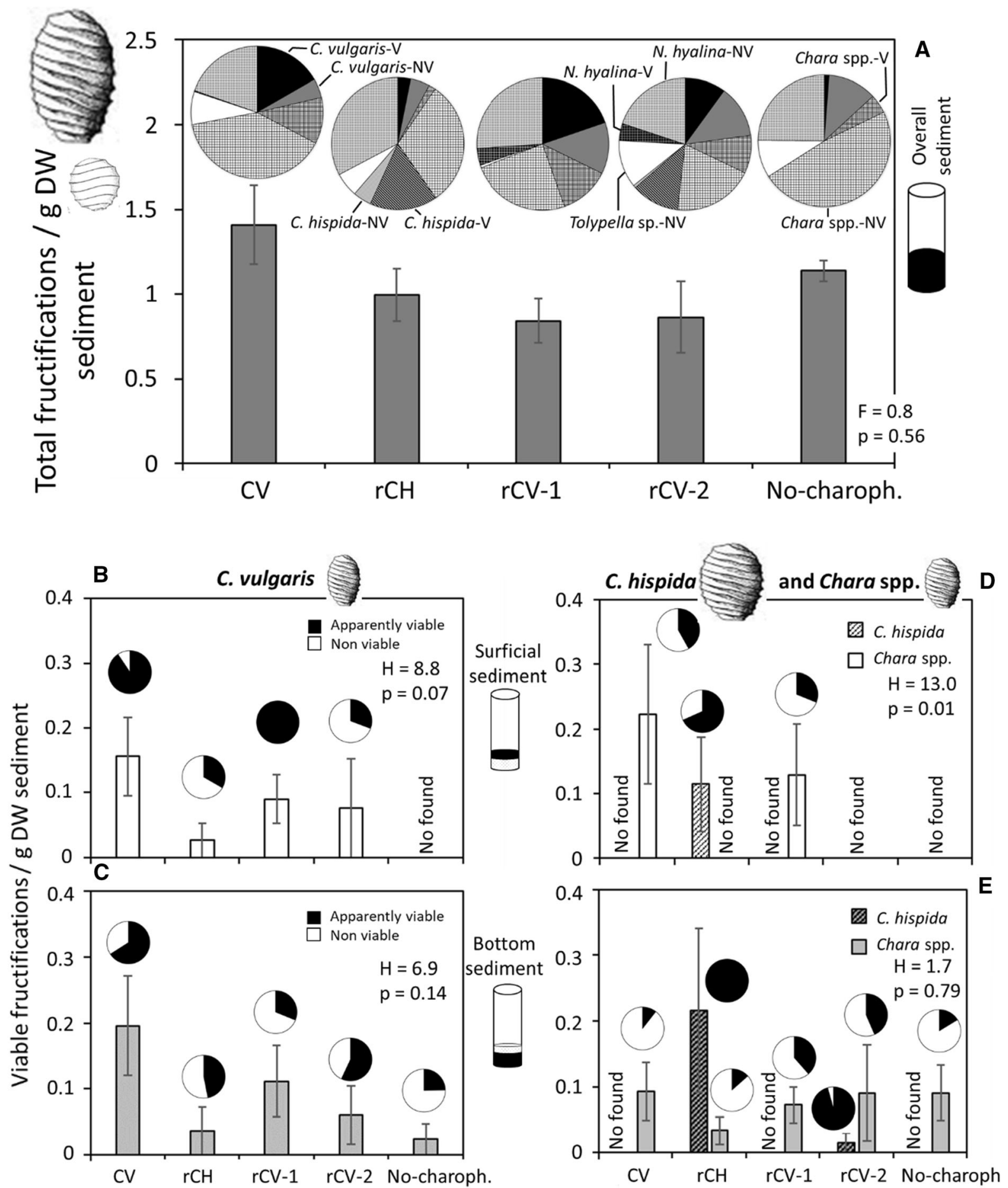

Fig. 6 A Density of charophyte fructifications in the 3-cm sediment layer under the different conditions. Abbreviations as in Fig. 2. Density of viable Chara vulgaris (B), Chara hispida and Chara spp. (D) fructifications in the $1 \mathrm{~cm}$ surficial sediment layer and in the $2 \mathrm{~cm}$ bottom sediment layer $(\mathbf{C}-\mathbf{E})$. Vertical thin bars indicate standard errors $(n=6)$. ANOVA $F$ or Kruskal-
Wallis $H$ and $P$-values are shown on each graph. The sector graphs in A represent the mean percentage of each species the fructifications belong to (in their viable: $\mathrm{V}$ and non-viable state: $\mathrm{NV}$ ). The sector graphs in $\mathbf{B}-\mathbf{E}$ represent the mean percentage of apparently viability (black area) out of total fructifications of each charophyte taxon 
sed., respectively), and there was approximately a twofold higher density in the surficial compared to the bottom layers (Fig. 3B, C) in all conditions $(F=9.8$; $P=0.003)$. The percentage of viability was maximum (94-97\%) in the $\mathrm{CV}$ and $\mathrm{rCH}$ conditions in both layers.

The mean density of ostracod remains in the overall sediment ranged from 9 to 32 doubled valves/g DW sed. (Fig. 4A). The density of remains in the surficial sediment was 1.7 greater than in the bottom layers (Fig. 4B, C). Foraminifers were detected in almost $70 \%$ of sediment samples $(0.8 \pm 0.2$ ind./g DW sed.).

The bacterial density was not statistically different among conditions considering the overall sediment or the surficial layer (Fig. 5A, B); in the surficial layer, the mean density was $4.5 \pm 0.3 \cdot 10^{9}$ bacteria/g DW sed. In the bottom sediment, the bacterial mean density ranged from $0.9 \times 10^{9}$ to $3.2 \times 10^{9}$ bacteria/g DW sed. (Fig. 5C), and it was higher in the $\mathrm{rCH}$ and $\mathrm{rCV}-2$ conditions compared to $\mathrm{CV}$ and $\mathrm{rCV}-1$; the latter two had similar bacterial densities to the sites with no charophytes.

A total of 28 taxa were identified in the periphyton biofilm: 26 diatoms (taxa list in Table A1), 1 cyanobacterium (Lyngbya sp.) and 1 euglenophyte (Trachelomonas sp.). The richness range was 4-13 taxa. Mean richness was statistically different among conditions (Fig. 5D). The mean value in the $\mathrm{CV}$ condition was $7.6 \pm 0.4$ taxa, $9.8 \pm 0.4$ taxa in $\mathrm{rCH}$, rCV1 and rCV2, and $7.3 \pm 1.8$ in the sites with no charophytes. The Shannon diversity index ranged between 0.4 and 1.8 nats; the mean effective number of species was $3.6 \pm 0.3$ (range 1.5-6.3) with no statistically significant differences among conditions. Most taxa did not reach $25 \%$ of the biomass share in each sample, only 10 taxa represented $25 \%$ in some samples, and only Navicula sp.1 was found represented in all samples (Table A1). SIMPER analysis indicated that Pleurosigma sp. (28\% contribution to dissimilarity), Entomoneis alata Ehrenberg (16\%), and Nitzschia tryblionella Hantzsch (12\%), were the taxa which contributed more than $10 \%$ contribution to differences in composition between conditions (Fig. 5E). Pleurosigma sp. showed the highest percentage of biomass in $\mathrm{rCH}$ and $\mathrm{rCV}-2(31 \%$ and $25 \%$ respectively), E. alata in $\mathrm{CV}$ and $\mathrm{rCV}-1$ (27\% and $20 \%$ ), and N. tryblionella in rCV-2 (36\%). However, considering all the taxa, the periphyton assemblages were not discriminated among conditions (the dendrogram did not cluster limnocorrals from different conditions). The mean periphytic biomass ranged between 0.002 and $0.295 \mathrm{~mm}^{3} / \mathrm{g} \mathrm{DW}$ sed., and it was statistically different among conditions (Fig. 5E). A similar biomass was reached in $\mathrm{rCH}, \mathrm{rCV}-2$ and $\mathrm{rCV}-1$ (mean $0.079 \pm 0.016 \mathrm{~mm}^{3} / \mathrm{g} \mathrm{DW}$ sed.). Although the biomass was lower in $\mathrm{CV}$, it was sevenfold greater than that found in the no-charophytes sites, and similar to $\mathrm{rCV}-1$.

The mean density of total charophyte fructifications (oospores and gyrogonites, viable and non-viable) ranged from 0.8 to 1.4 fruct./g DW sed. in the overall sediment layer and there were no statistical differences among conditions (Fig. 6A). The fructifications belonged to $\mathrm{CH}, \mathrm{CV}$, Chara spp., Nitella hyalina (De Candolle) Agardh and Tolypella sp. None of the Tolypella remains were viable, and $83-100 \%$ of $N$. hyalina oospores were non-viable; $N$. hyalina oospores represented $25 \%$ of total fructifications in the $3 \mathrm{~cm}$ sediment layer. In the surficial layer, viable CV fructifications (Fig. 6B) were slightly more abundant in the CV limnocorrals $(0.16 \pm 0.06$ vs. $0.06 \pm 0.02$ fruct./g DW sed. as mean of the other three conditions, although the differences were not statistically significant) and they were absent in the no-charophytes sites. The percentage of viability regarding CV total fructifications was higher in the surficial compared to the bottom sediments (Fig. 6B, C). $\mathrm{CH}$ fructifications were found only in the $\mathrm{rCH}$ limnocorrals $(0.11 \pm 0.07$ fruct./g DW sed.; Fig. 6D). Fructifications assigned to other Chara species (Fig. 6D, E) were found only in the $\mathrm{CV}$ and $\mathrm{rCV}-1$ limnocorrals in the surficial sediment but they were present in all conditions in bottom the layers with mean values not statistically different among conditions.

In the surficial layer, and considering all the limnocorrals, fructification abundance was related to a higher abundance of periphyton (20\% explained variance; Table 1), and this was particularly observed in the $\mathrm{rCH}$ limnocorrals ( $88 \%$ explained variance). It was in these limnocorrals where the higher fructification densities were also related to higher ostracod valve densities. In the CV limnocorrals, there was a moderate positive relationship between ephippia and ostracod valves. In the rCV (1 and 2) limnocorrals, a clear negative relationship was found between cladoceran ephippia and periphyton abundance (50\% explained variance). In the sediment free of charophytes for years, only the presence of periphyton was 
related to a higher surficial bacteria density ( $98 \%$ explained variance).

\section{Discussion}

Our study corroborates that submerged macrophytes favour the abundance and diversity of zooplankton in the water column in comparison to vegetation-free zones (Meerhoff et al., 2007) and validates part of our first hypothesis (the presence of charophyte meadows will benefit the abundance of cladocerans and ostracods in the water and this will be reflected in their sediment remains). In our case, the presence of the macroalgae would have benefited the presence of cladocerans in the water column of the limnocorrals with vegetation, inferred by means of the higher density of resting eggs in the sediments, providing habitat, a refuge against predators and a certain degree of environmental heterogeneity. Moreover, the highest ephippia density was found where CV was planted (more than 8 ephippia $/ \mathrm{cm}^{2}$, a twofold greater density compared to the limnocorrals with recruited charophytes, or threefold higher than in sites with no charophytes). From these data it seems that the introduction of well-developed cultures of charophytes (CV) in the limnocorrals favours the density of ephippia in the sediments, in comparison with limnocorrals with recruited $\mathrm{CH}$ and $C$. vulgaris var. longibracteata. However, this might not be the single cause, since the mean density of apparently viable ephippia in recruited $\mathrm{CH}$ limnocorrals (approximately 4 ephippia $/ \mathrm{cm}^{2}$ ) is similar to the density recorded in the same limnocorrals at the end of the experiment performed by Puche et al. (2021) (3 ephippia/ $\mathrm{cm}^{2}$; Table A3), when the charophytes were also introduced as well-developed cultures in April 2018. The different morphology of the vegetation influences the composition of the invertebrate community as well as the preference of these for their associations (Hann, 1995). A long time ago, Krecker (1939) established that the abundance of invertebrate by unit of macrophyte biomass varied depending on the plant species, and this was higher in plants with fine-divided leaves. Here, both $\mathrm{CH}$ and $\mathrm{CV}$ (including the variety longibracteata) have basically the same structure, but $\mathrm{CH}$ is a larger-sized, more robust charophyte and all its structures (branchlets, ramifications, etc.) are thicker and larger than those of $\mathrm{CV}$. For this reason, the meadow structure formed by $\mathrm{CV}$ might result in a higher habitat complexity, and therefore, the effect on the cladocerans could be analogous to the effect produced by fine-divided versus wider leaves of other macrophytes. Another aspect that must be considered in the relationship of zooplankton with macrophytes is the possible negative effect of allelopathic substances produced by the plants (Hilt \& Gross, 2008; Rojo et al., 2013). Experiments with macrophyte monocultures have demonstrated that the allelopathic effects are species-specific (Hilt \& Gross, 2008). The effect of exudate compounds of $\mathrm{CV}$ and $\mathrm{CH}$ on the cladoceran populations could be different, and this issue deserves future research. Despite all the possible mechanisms involved have not been determined here, our second hypothesis (... but there will be species-specific differences depending on particular traits of each charophyte species) is confirmed concerning cladocerans. On the other hand, former studies in the Educative lagoon (unpublished data) reported the presence of species forming 1 and 2-egg ephippia, the former being the most abundant (mainly Chydorus sphaericus Mueller and Alona rectangula Sars, with maximum abundances of 44 and 34 ind./1 in 2018, respectively; one-time blooms of Daphnia magna Straus, producers of 2-egg ephippia, also occurred; Rodrigo \& Segura, 2020). This is in accordance with our finding of a higher density of 1-egg ephippia in the sediments along with 2-egg ephippia.

Ostracods are one of the groups which have experienced an important loss of diversity in wetlands in the western Mediterranean (Poquet et al., 2008), the Albufera de València lagoon included. However, we have evidence that ostracods proliferate in the conditions developed within the Tancat de la Pipa, reaching high biomass production efficiencies (Rodrigo et al., 2018). Mean densities of ostracod double-valves found in this study (9-35 ind./g DW sed.) are of the same order of magnitude as those found in the 25-30 cm deep sediment layers of the Albufera de València lagoon reported by Marco-Barba et al. (2013), but much higher than those found in the shallower sediment layers which corresponded to the period from which the lagoon was affected by the eutrophication process. We did not find strong statistical evidence that the presence/absence of charophytes, the particular species, or the form that they appear in the limnocorrals (planted or recruited from the sediment) influence the abundance of ostracod 
valves in the sediments. We must keep in mind that several valves found in the sediment might derive from the same individual, since their valves grow discontinuously by moulting, i.e., their instars shed their valves and form new ones in defined ontological stages (Meisch, 2000). Moreover, some studies (e.g. Hann, 1995) have demonstrated that species composition of invertebrates is generally similar in different macrophyte species; however, Cyr \& Downing (1988) reported differences in the ostracod group for different macrophyte species, but this study was carried out on several genera of higher plants, not with charophytes. Consequently, ostracod valves contained in the sediment do not support our first and second hypotheses.

One less-explored aspect is whether macrophyte meadows, once they have died due to desiccation of the wetland or lagoon (naturally or human-induced for management purposes), can act as a potential substrate for the conservation of zooplankton resting eggs. Eskinazi-Sant'Anna \& Pace (2018) found that dry submerged vegetation was a better source of zooplankton diaspores than the sediment. The presence of a layer of dry vegetation reduced sediment erosion caused by the wind when waterbodies were dry. In our case, the vegetation of $2018 \mathrm{CH}$ limnocorrals was harvested before the drying out of the lagoon for biomass determination, but only the parts above the substrate were cut. All vegetation of the rhizosphere remained. Thus, rhizoids and portions of charophytes inside the sediment might have increased the retention of resting eggs, in comparison to bare sediment. This clearly favour the diversity and resilience of zooplankton after disturbances (i.e. desiccation), and it might contribute to the dispersal to new habitats (Battauz et al., 2017; Eskinazi-Sant'Anna \& Pace, 2018). The apparently viability of resting eggs is also positively influenced by the presence of submerged vegetation, particularly planted CV (97\% viable ephippia versus $79 \%$ in bare sediment). Ephippia might be more viable (at least less damaged) with charophyte presence as they protect the resting forms against external dangers (senescence produced by UV radiation, egg predators, abrasion, etc.), particularly during dry periods. Therefore, our third hypothesis (the presence of charophytes will be a potential substrate for better conservation of cladoceran resting eggs) is verified. Some studies have reported that the extension of the dry periods may negatively affect the viability of the resting forms (Havel et al., 2000;
Boven \& Brendock, 2009). The dry period experienced by the Educative lagoon was not too long (5 months), and it seems it did not negatively influence the apparent viability of the ephippia, indeed, it was higher than in 2018 (around 50\% in the limnocorrals where $\mathrm{CH}$ was planted; Table A3).

Regarding our fourth hypothesis (the presence of charophytes will increase the periphytic biofilm—and bacterial-biomass and different charophyte species will have a different composition associated), we have shown that charophyte meadows fuel the periphytic biofilm; this effect was observed a few months after the first charophyte planting $(\mathrm{CH})$ in the limnocorrals in 2018 (Puche et al., 2021). Periphyton benefit from the modifications that charophyte meadows cause in the sediment, corroborating our fourth hypothesis. These modifications are physical (e.g. filtering ultraviolet radiation-Puche et al., 2021, stabilization of surface sediment for attached biofilms provided by both the rhizoids and basal parts of the shoots) and chemical (e.g. contribution with organic matter and compounds exudation; Morina et al., 2018; Dai et al., 2019). There was a higher content of $C, N$ and $P$ in the surficial sediments where the charophytes grew than in the sites with no charophytes (means and standard errors of $6.6 \pm 0.2 \% \mathrm{C}, \quad 0.92 \pm 0.04 \% \mathrm{~N}$ and $0.055 \pm 0.001 \% \mathrm{P}$ versus $4.9 \pm 1.5 \% \mathrm{C}$, $0.66 \pm 0.21 \% \mathrm{~N}$ and $0.042 \pm 0.013 \% \mathrm{P}$, respectively; M. Álvarez-Cobelas, pers. comm.). Moreover, in this study we have shown that some species of diatoms are associated with one or another charophyte species, suggesting that even though overall assemblage dissimilarity was not significant between the different meadows, a few individual species increase periphyton diversity within the wetland. This uniqueness may be because the effect of charophytes on benthic diatoms is also species-specific and very local (Rojo et al., 2017a). Hence, if meadows of different species of charophytes were conserved, the diversity of the wetland, as a whole, would be favoured. Diatoms were the numerically dominant component of the periphyton biofilm. These benthic microalgae contribute to film cohesion through the production of extracellular mucilage and attachment structures, forming the matrix of the periphyton (Mazzei et al., 2020). Large diatoms [e.g. Pleurosigma sp., Surirella ovalis Brébisson and Nitzschia sigmoidea (Nitzsch) Smith] consolidated this matrix in which, also, $69 \%$ of the constituent 26 species were small-sized diatoms, 
which herbivores can easily ingest. Thus, the periphyton is a source of resources that allows the connection between the decomposition of organic matter in the sediment and the mobilization of these nutrients towards the pelagic habitat. This role is shown in this study with the likely herbivory of "planktonic" cladocerans over the periphyton, which was previously modelled by Puche et al. (2020) in an indoormesocosm environment and that places periphyton as a source of production for other organisms also, such as fish (van Dam et al., 2002). On the other hand, the periphyton has great value as an indicator of changes in the water quality in wetlands (e.g. salinization and eutrophication will cause shifts in its composition, thus, different compositions can be found according to the local environment; Mazzei et al., 2020).

Bacteria, which constitute an essential group in the wetlands' sediment for nutrient cycling, reached more abundant communities in the bottom sediment layers where most meadows grew. This layer is an oxicanoxic space, rich in organic matter (Morina et al., 2018; Puche et al., 2021), and clearly influenced by the rhizoidal charophyte system which can penetrate to this depth, structuring the sediment. The highest mean bacterial density found in the bottom sediment layer was recorded for $\mathrm{rCV}-2$ limnocorrals and this condition also had the highest percentage of carbon and phosphorus in such a sediment layer $(5.6 \pm 0.7 \% \mathrm{C}$ and $0.047 \pm 0.006 \% \mathrm{P}$ versus $4.2 \pm 0.9 \% \mathrm{C}$ and $0.038 \pm 0.008 \% \mathrm{P}$ in the sediment with no charophytes; M. Álvarez-Cobelas, pers. comm.). The surficial sediment might be more exposed to the homogenizing flow of water than the bottom layer; this would explain the lack of statistically significant differences in bacterial densities among conditions in the first-centimetre sediment layer. Meadows can stabilize fine sediments (which can be flown out by wind and currents); further analyses of sediment grain size would be a good complement to discuss this indirect effect of charophyte meadows on surface sediment. Hence, our fourth hypothesis is partially supported by bacteria, only for these microorganisms in the bottom sediment layers.

With regard to the fifth hypothesis (the dry period will change the composition of periphyton biofilm in favour of more adapted species, and will stimulate the germination of charophyte oospores), we have also demonstrated that the influence of charophytes on periphytic biofilm lasts after a period of desiccation, a frequent process in coastal wetlands under a Mediterranean climate. In the periphyton of the current study's limnocorrals there were no cyanobacteria because diatoms are more resistant to both desiccation and the consequent increase in UV radiation due to the loss of water depth (Aguirre et al., 2018). Consequently, diatoms are selected by these global change-related factors. Related to this, we observed that the initial periphyton after the planting of $\mathrm{CH}$ in the first experiment (2018; Puche et al., 2021) consisted of chlorophytes and diatoms, but in this second experiment, it only diatoms were present, as the lagoon had gone through a desiccation period. Hence, the first part of the fifth hypothesis is verified.

The charophyte fructifications found in the sediments of our study correspond to the charophytes introduced during our experimentation, but there were also fructifications produced in the past (Rodrigo et al., 2010; Rodrigo \& Alonso-Guillén, 2013), since, in those sites with no planted charophytes, oospores and gyrogonites were found, particularly oospores belonging to the Nitella and Tolypella genera and, moreover, they were found with almost the same representation in the five conditions. The fructifications found belong to five different charophyte taxa out of ten which were identified in previous studies of the Albufera de València and the Educative lagoons (Rodrigo et al., 2013). Their presence in our sediment samples is explained because the previous rice fields of the Tancat de la Pipa (in a period during which charophytes can also grow in such flooded areas) were constructed by filling parts of the Albufera lagoon with soil, and later the works carried out to transform the former rice fields into the current Reserve Area (the construction of the lagoon basin using machinery) moved deeper sediments upwards, even those corresponding to the saline periods of the Albufera lagoon (Rodrigo et al., 2010). This situation would also explain the presence of marine foraminifer shells in most of the sediment samples studied. As expected, the density of $\mathrm{CV}$ fructifications was higher in the $\mathrm{CV}$ limnocorrals, and also in those with the spontaneous growth of $C$. vulgaris var. longibracteata and higher in the surficial than in the bottom sediment layers. However, the densities were much lower than in other sites of the Albufera de Valencia Natural Park (7 fruct./g DW sed. in Rodrigo et al., 2010, and 13 fruct./ g DW sed. in Rodrigo \& Alonso-Guillén, 2013), indicating a poor sediment seed bank for this species in 
the Educative lagoon in the first $3 \mathrm{~cm}$ sediment layer. $\mathrm{CH}$ fructifications were found only where this species was introduced. The average density obtained in our study $\left(0.05\right.$ fruct. $\left./ \mathrm{cm}^{2}\right)$ is slightly lower than the value obtained after planting $\mathrm{CH}$ for the first time in 2018 in the Educative lagoon ( 0.15 fruct. $/ \mathrm{cm}^{2}$; Table A3). This is due to recruitment, which was produced from the germination of the oospores in the sediment bank originated during the growth period of the 2018 experiment, and therefore, the reserves have decreased, with no time to be enriched again with fructifications produced by $\mathrm{CH}$ grown during the 2019 experiment. Regarding the differences in the density of $\mathrm{CV}$ and $\mathrm{CH}$ fructifications, the explanation is found in the high reproductive capacity of the former. This species has very rapid growth rates and a high production of small fructifications. Its smaller oospores will ripen before those of $\mathrm{CH}$. A study on sexual reproduction phenology of $\mathrm{CH}$ in an interdunal pond within the Albufera de València Natural Park reported that oospore ripening, after which the oospores detach from the plant and fall down to the sediment, took place predominately in July (Calero \& Rodrigo, 2019). The samples in our study were taken in June when the ripening period had not reached its maximum. Moreover, substantial differences have been described in the reaction of these species when faced with warming. CV growth was enhanced with a temperature increase in laboratory experiments (Rojo et al., 2017b, 2019; Puche et al., 2018). Therefore, the progressive temperature increase as the spring drew on until the sampling date, facilitated a higher development of $\mathrm{CV}$ meadows compared to $\mathrm{CH}$, which, moreover, started from the recruitment from the sediment bank, instead of from well-grown cultures as in the case of CV. The $1 \mathrm{~cm}$ surficial sediment layer would correspond to approximately one year, based on the maximum sedimentation rates of $0.8-1 \mathrm{~cm} /$ year reported by Rodrigo \& Alonso-Guillén (2013) for the eutrophication period in the Albufera de València, or $0.7 \mathrm{~cm} /$ year estimated by Enache et al. (2019) for Danube delta wetlands. Moreover, considering that the lagoon was dried out from August 2018, the complete sedimentation of all the material contained in the water column would increase the thickness of the sediment layer. The absence of CV viable fructifications in this $1 \mathrm{~cm}$ sediment layer in the sites outside the limnocorrals, but its presence in the deeper sediment, is remarkable. This clearly indicates that the propagules in the sub-surficial sediment found at the end of our experiment were produced in past times, while those found in the surficial sediment from inside the charophyte-planted limnocorrals are the result of this planting, plus the spontaneous germination produced inside the "no-planted charophyte" limnocorrals from deeper-sediment oospores, which was stimulated by the desiccation period (supporting the second part of our fifth hypothesis). Moreover, this recruitment was facilitated by (i) the disturbance caused by our experimentation when we introduced the same substrate with no-charophytes in the "nocharophyte" limnocorrals, and (ii) the presence of limnocorral lateral nets, which protected the germination from disturbances caused by exotic fish (mainly carps) and American crayfish, and top nets which prevented the grazing from herbivorous birds (mainly ducks and coots) which inhabit the wetland (Rodrigo et al., 2013). Thus, C. vulgaris var. longibracteata took advantage of the empty niche in those limnocorrals with no planted charophytes, germinating some oospores and quickly developing a large biomass. Actually, CV is one of the first species colonizing aquatic ecosystems under the restoration process (Rodrigo et al., 2010).

\section{Conclusion}

Sediments linked to the development of charophyte meadows are the scenario of a complex network of biotic interactions, and changes in the physical and chemical features of this habitat (Puche et al., 2021), which govern the dynamics of micro-herbivores and periphyton, and the sub-surficial layers influenced by the rhizosphere. Thus, we might say that charophytes are not only ecosystem engineers in the water column, as previously proposed (Kufel \& Kufel, 2002), but they possess some aspects of ecosystem engineers in the sediment. The specific microhabitat generated by each species of charophyte has been reflected in the different abundances and relationships between the analysed components, firstly establishing a divergence with the sediment without meadows and, secondly, a distinction between the meadows of $\mathrm{CH}$ and $\mathrm{CV}$ that exhibit particular morphology-architecture, might exudate different metabolites and have different allelopathic capacities over both microalgae and microinvertebrates (Rojo et al., 2013, 2017a). Similar 
explanations can be used to justify the great development of periphyton and its drought resistance under charophytes and to explain the presence and viability of the resting forms. Our results support the importance of the charophytes-cladocerans tandem in the connection among wetland food-web components (Puche et al., 2020). Moreover, knowledge concerning the structure and dynamics of resting egg and fructification sediment bank, and how this is related to the composition of the community (specific and genetic pool), is helpful to develop tools to monitor the effects caused by global phenomena affecting restoration and conservation, such as climate change (Brendock \& De Meester, 2003; Angeler, 2007). We have demonstrated that $\mathrm{CV}$, which has been recently proposed as one of the selected species for replanting in threatened Mediterranean wetlands based on growth criteria (Rodrigo \& Carabal, 2020; Rodrigo, 2021), together with $\mathrm{CH}$, are a good species combination that favours the relationships with the plankton and, at least, some components of the benthic communities. This study allows us to stress the relevance of the charophytesediment interactions for biodiversity and habitat conservation.

Acknowledgements We are thankful to Cristina Navarro, Ester Sánchez, Amalia Jurado and Jorge Farga for their collaboration in sediment processing and counting, to Carlos Rochera (Cavanilles Institute of Biodiversity and Evolutionary Biology, University of Valencia), who helped with the cytometry, to Michał Brzozowski (Adam Mickiewicz University, Poznań, Poland) for helping with the field work, as well as all the management staff of the Tancat de la Pipa. Dr. M. Álvarez-Cobelas and Dr. S. Sánchez-Carrillo (National Museum of Natural Sciences, CSIC, Madrid) provided data on $\% \mathrm{C}, \% \mathrm{~N}$ and $\% \mathrm{P}$ from sediments. Daniel Sheerin, a native English teacher and editor, improved the language in the manuscript.

Author contributions All authors listed on the title page have contributed significantly to the work. MAR, CR and EP conceived and designed the study; EP and MAR performed the field work; MS identified and counted the samples of microalgae and cyanobacteria; MAR and AA processed the sediment samples and counted ephippia, ostracod valves and charophyte fructifications; EP analysed the bacteria samples; MAR, CR and EP analysed and interpreted the data; MAR wrote the manuscript, which was finally reviewed by all authors.

Funding Open Access funding provided thanks to the CRUECSIC agreement with Springer Nature. This study has been undertaken within the CGL2014-5402 Project, funded by the Spanish Ministry of Economy and Competitiveness (including FEDER support).
Data availability Not applicable.

Code availability Not applicable.

\section{Declarations}

Conflict of interest The authors have no conflict of interest to declare.

Consent for publication Not applicable.

Ethical approval Not applicable.

Informed consent Not applicable.

Open Access This article is licensed under a Creative Commons Attribution 4.0 International License, which permits use, sharing, adaptation, distribution and reproduction in any medium or format, as long as you give appropriate credit to the original author(s) and the source, provide a link to the Creative Commons licence, and indicate if changes were made. The images or other third party material in this article are included in the article's Creative Commons licence, unless indicated otherwise in a credit line to the material. If material is not included in the article's Creative Commons licence and your intended use is not permitted by statutory regulation or exceeds the permitted use, you will need to obtain permission directly from the copyright holder. To view a copy of this licence, visit http://creativecommons.org/licenses/by/4.0/.

\section{References}

Aguirre, L. E., L. Ouyan, A. Elfwing, M. Hedblom, A. Wulff \& O. Inganäs, 2018. Diatom frustules protect DNA from ultraviolet light. Scientific Reports 8: 5138.

Alekseev, R. V., B. De Stasio \& J. J. Gilbert, 2007. Diapause in Aquatic Invertebrates: Theory and Human Use, Vol. 84. Springer, Dordrecht.

Angeler, D. G., 2007. Resurrection ecology and global climate change research in freshwater ecosystems. Journal of North American Benthological Society 26: 12-22.

Battauz, Y. S., S. B. J. De Paggi \& J. C. Paggi, 2017. Macrophytes as dispersal vectors of zooplankton resting stages in a subtropical riverine floodplain. Aquatic Ecology 51: 191-201.

Blindow, I., 1992. Decline of charophytes during eutrophication: comparison with angiosperms. Freshwater Biology 28: 9-14.

Blindow, I., A. Hargeby \& S. Hilt, 2014. Facilitation of clearwater conditions in shallow lakes by macrophytes: differences between charophyte and angiosperm dominance. Hydrobiology 737: 99-110.

Boven, L. \& L. Brendock, 2009. Impact of hydroperiod on seasonal dynamics in temporary pool cladocerans communities. Archiv für Hydrobiologie 174: 147-157. 
Brendock, L. \& L. De Meester, 2003. Egg banks in freshwater zooplankton: evolutionary and ecological archives in the sediment. Hydrobiologia 491: 65-84.

Calero, S. \& M. A. Rodrigo, 2019. Reproductive phenology of submerged macrophytes: a tracker of year-to-year environmental variations. Journal of Vegetation Science 30: 1217-1227.

Canfield, D. E., A. N. Glazer \& P. G. Falkowski, 2010. The evolution and future of earth's nitrogen cycle. Science 330: 192-196.

Cyr, H. \& J. A. Downing, 1988. The abundance of phytophilous invertebrates on different species of submerged macrophytes. Freshwater Biology 20: 365-374.

Dai, Y., J. Wu, F. Zhong, N. Cui, L. Kong, W. Liang, et al., 2019. Macrophyte identity shapes water column and sediment bacterial community. Hydrobiologia 835: 71-82.

Enache, I., L. I. Florescu, M. Moldoveanu, M. I. Moza, L. Parpală, C. Sandu, et al., 2019. Diversity and distribution of Daphnia across space and time in Danube Delta lakes explained by food quality and abundance. Hydrobiologia 842: 39-54.

Eskinazi-Sant'Anna, E. M. \& M. L. Pace, 2018. The potential of the zooplankton resting-stage bank to restore communities in permanent and temporary waterbodies. Journal of Plankton Research 40: 458-470.

Hann, B. J., 1995. Invertebrate associations with submersed aquatic plants in a prairie wetland. UFS (Delta Marsh). Annual Reports 30: 78-84.

Havel, J. E., E. M. Eisenbacher \& A. A. Black, 2000. Diversity of zooplankton in riparian wetlands: colonization and egg banks. Aquatic Ecology 34: 63-76.

Hilt, S. \& E. M. Gross, 2008. Can allelopathically active submerged macrophytes stabilise clear-water states in shallow eutrophic lakes? Basic and Applied Ecology 9: 422-432.

Krecker, F., 1939. A comparative study of the animal population of certain submerged aquatic plants. Ecology 20: 553-562.

Kufel, L. \& K. Kufel, 2002. Chara beds acting as nutrient sinks in shallow lakes. Aquatic Botany 72: 249-260.

Marco-Barba, J., F. Mesquita-Joanes \& M. R. Miracle, 2013. Ostracod palaeolimnological analysis reveals drastic historical changes in salinity, eutrophication and biodiversity loss in a coastal Mediterranean lake. The Holocene 23: $556-567$.

Mazzei, V., B. J. Wilson, S. Servais, S. P. Charles, J. S. Kominoski \& E. E. Gaiser, 2020. Periphyton as an indicator of saltwater intrusion into freshwater wetlands: insights from experimental manipulations. Ecological Applications 30: 02067.

Meerhoff, M., C. Iglesias, F. T. De Mello, J. M. Clemente, E. Jensen, T. L. Lauridsen, et al., 2007. Effects of habitat complexity on community structure and predator avoidance behavior of littoral zooplankton in temperate versus subtropical shallow lakes. Freshwater Biology 52: 1009-1021.

Meisch, C., 2000. Freshwater Ostracoda of Western and Central Europe (Süßwasserfauna von Mitteleuropa 8/3) Spektrum Akademischer Verlag, Heidelberg.

Moreno, E., C. Pérez-Martínez \& J. M. Conde-Porcuna, 2016. Dispersal of zooplankton dormant propagules by wind and rain in two aquatic systems. Limnetica 35: 323-336.
Morina, J. C., E. M. Morrissey \& R. B. Franklin, 2018. Vegetation effects on bacteria and denitrifier abundance in the soils of two tidal freshwater wetlands in Virginia. Applied and Environmental Soil Science 4727258.

Nevalainen, L. \& T. P. Luoto, 2017. Relationship between cladoceran (Crustacea) functional diversity and lake trophic gradients. Functional Ecology 31: 488-498.

Poquet, J. M., F. Mezquita-Joanes, J. Rueda \& M. R. Miracle, 2008. Loss of Ostracoda biodiversity in Western. Mediterranean wetlands. Aquatic Conservation: Marine and Freshwater Ecosystems 18: 280-296.

Puche, E., S. Sánchez-Carrillo, M. Álvarez-Cobelas, A. Pukacz, M. A. Rodrigo \& C. Rojo, 2018. Effects of overabundant nitrate and warmer temperature on charophytes: the role of plasticity and local adaptation. Aquatic Botany 146: 15-22.

Puche, E., C. Rojo \& M. A. Rodrigo, 2020. Multi-interaction network performance under global change: a shallow ecosystem experimental simulation. Hydrobiologia 847: 3549-3569.

Puche, E., C. Rojo, M. Segura \& M. A. Rodrigo, 2021. Macrophyte meadows mediate the response of the sediment microbial community to ultraviolet radiation. Hydrobiologia 848: 4569-4583.

Rodrigo. M. A., 2021. Wetland restoration with hydrophytes: a review. Plants 10(6): 1035.

Rodrigo, M. A. \& J. L. Alonso-Guillén, 2013. Assessing the potential of Albufera de València Lagoon sediments for the restoration of charophyte meadows. Ecological Engineering 60: 445-452.

Rodrigo, M. A. \& N. Carabal, 2020. Selecting submerged macrophyte species for replanting in Mediterranean eutrophic wetlands. Global Ecology and Conservation 24: e01349.

Rodrigo, M. A. \& M. Segura, 2020. Plankton participation in the performance of three constructed wetlands within a Mediterranean natural park. Science of the Total Environment 721: 137766.

Rodrigo, M. A., J. L. Alonso-Guillén \& I. Soulié-Märsche, 2010. Reconstruction of the former charophyte community out of the fructifications identified in Albufera de València lagoon sediments. Aquatic Botany 92: 14-22.

Rodrigo, M. A., C. Rojo, J. L. Alonso-Guillén \& P. Vera, 2013. Restoration of two small Mediterranean lagoons: the dynamics of submerged macrophytes and factors that affect the success of revegetation. Ecological Engineering 54: 1-15.

Rodrigo, M. A., C. Rojo, M. Segura, J. L. Alonso-Guillén, M. Martín \& P. Vera, 2015. The role of charophytes in a Mediterranean pond created for restoration purposes. Aquatic Botany 120: 101-111.

Rodrigo, M. A., J. Claros, M. Lassalle, L. Moreno, M. Segura, A. Valentín, et al., 2018. Assessing the effect of emergent vegetation in a surface-flow constructed wetland on eutrophication reversion and biodiversity enhancement. Ecological Engineering 113: 74-87.

Rojo, C., M. Segura \& M. A. Rodrigo, 2013. The allelopathic capacity of submerged macrophytes shapes the microalgal assemblages from a recently restored coastal wetland. Ecological Engineering 58: 149-155.

Rojo, C., Z. Mosquera, M. Álvarez-Cobelas \& M. Segura, 2017a. Microalgal and cyanobacterial assemblages on 
charophytes: a metacommunity perspective. Fundamental and Applied Limnology 190: 97-115.

Rojo, C., M. Carramiñana, D. Cócera, R. Gwen-Page, E. Puche, S. Calero \& M. A. Rodrigo, 2017b. Different responses of coexisting Chara species to foreseeable Mediterranean temperature and salinity increases. Aquatic Botany 138: $53-63$.

Rojo, C., E. Puche \& M. A. Rodrigo, 2019. The antagonistic effect of UV radiation on warming or nitrate enrichment depends on ecotypes of freshwater macroalgae (Charophytes). Journal of Phycology 55: 714-729. van Dam, A. A., M. C. Beveridge, M. E. Azim, \& M. C. J. Verdegem, 2002. The potential of fish production based on periphyton. Reviews in Fish Biology and Fisheries 12: $1-31$.

Publisher's Note Springer Nature remains neutral with regard to jurisdictional claims in published maps and institutional affiliations. 